\title{
ARTIGO
}

CO https://doi.org/10.22481/praxisedu.v16i37.6168

\section{WHAT PEDAGOGICAL INNOVATION DOES QUEER PEDAGOGY PROPOSE TO THE SCHOOL CURRICULUM?}

\author{
QUE INOVAÇÃO PEDAGÓGICA A PEDAGOGIA QUEER PROPÕE AO CURRÍCULO \\ ESCOLAR?
}

\section{¿QUÉ INNOVACIÓN PEDAGÓGICA PROPONE LA PEDAGOGÍA QUEER AL CURRÍCULO ESCOLAR?}

Carlos André Araújo Menezes

Universidade Federal de Sergipe - Brasil

Alfrancio Ferreira Dias

Universidade Federal de Sergipe - Brasil

Madson de Santana Santos

Universidade Federal de Sergipe - Brasil

\begin{abstract}
The purpose of this text is to problematize the potentialities of a queer pedagogy and curriculum at school. We problematize the argument that queer pedagogy proposes a new political stance, inserting new strategies, attitudes, subversive pedagogical procedures, demarcating possibilities of negotiation in the school space. We concluded that making one finding the school curriculum strange becomes one of the innovations that queer pedagogy proposes to students and teachers today.
\end{abstract}

Keywords: Queer Pedagogy. Queer Curriculum. Pedagogical Innovation.

Resumo: O propósito desse texto é problematizar as potencialidades de uma pedagogia e um currículo queer na escola. Problematizamos o argumento de que a pedagogia queer propõe uma nova postura política, inserindo novas estratégias, atitudes, procedimentos pedagógicos subversivos, demancando possibilidades de negociação no espaço escolar. Conclui-se que, estranhar o currículo da escola, passar a ser uma das inovações que a pedagogia queer propõe a a@s estudantes e professor@s hoje.

Palavras-chave: Pedagogia Queer. Currículo Queer. InovaçãoPedagógica.

Resumen: El propósito de este texto es problematizar las potencialidades de una pedagogía queer y un currículo en la escuela. Problematizamos el argumento de que la pedagogía queer propone una nueva postura política, insertando nuevas estrategias, actitudes, procedimientos pedagógicos subversivos, demarcando las posibilidades de negociación en el espacio escolar. Llegamos a la conclusión de que hacer que uno encuentre extraño el currículo escolar se convierte en una de las innovaciones que la pedagogía queer propone a los estudiantes y profesores de hoy.

Palabras clave: Pedagogía queer. Currículo queer. Innovación pedagógica. 


\section{Introductory Notes}

In the last two decades we have had experiences and teaching situations with students from different levels of education (kindergarten, elementary and high school) and, above all, in different institutions, from those in traditional communities (rural and quilombolas ), and also from larger cities. These teaching-pedagogical experiences have contributed to building us as teachers, and today they are also disrupting and deconstructing us daily. It is a fact that we do not know what sort of teachers we will be tomorrow.

The experience of "being a teacher" allows us to look at ourselves, to reflect from each contact with the other, with the different narratives and life histories of students and other school agents, surrounded by their personal identifications and subjectivities. As we recall some memories, we realize that these aspects were important for us to change, touch, awaken, and act, as Larrosa (2002, p. 21, our translation) argues: experience is "what happens to us, what touches us. Many things happen every day, but at the same time, almost nothing happens to us." The teaching experience also allowed us to reflect on how the pedagogical act can be a dialogic act, in which knowledge is produced in the relationship, in the daily life, in the mediation and, above all, in the importance we give to the roles played by all the school agents (students, teachers, parents, and managers).

We start this text from the premise that the learning process must go beyond the classrooms, the hallways, the library, the courtyard and the many other spaces of the school. It should surpass the walls, break down barriers and reach where the students are, in the places of socialization, where one lives and can learn, that is a "curriculum-as-life" (SOUSA, 2012), in which the relation of time and space impact on the relations and the socialization process, proposing reflections about identities and subjectivities that are increasingly decentered and conflicted (SOUZA, 2017; OLIVEIRA, 2013; SARAT;CAMPOS, 2014; THURLER; SANTOS, 2014; ALCANTARA; DIAS; GIVIGI, 2019).

The curriculum-as-life, according to Sousa (2012, p.20, our translation), "looks at the school with suspicion if it is not able to face the real problems that humanity goes through and does not do something to thwart them." In this perspective, how to think a school in a singular way? What is the school for? Who does it intend to educate? Why are there people still investing in generalized schooling? What bodies are accepted in the school? What expressions of gender and sexuality are allowed? From our professional experience, in general, there is an investment of some educational institutions in the schooling of a generalized, disciplined and invisible body (DIAS, 2014; CRUZ, 2015; LOURO, 2010; SANTANA, 2014; SANTOS; LAGE, 2017). In 
which, it is invested in technologies of normalization of the bodies in the school practices, with visible strategies of control and discipline (ALMEIDA, 2017; ANJOS; CARDOSO, 2014; FERREIRA, 2014; ROSENO; AUAD, 2019).

We need to be aware of the school we have. The school is alive, and it is crossed by the daily problems and actions of the people who constitute this place. In this perspective, this project of subjectivation of the gendered subject is not passively accepted by all students (DIAS; DANILO, 2015; CADILHE; CASTRO, 2019). Some bodies question and confront gender norms and many other possibilities of control of the bodies in school practices, as discussed by Cardoso and Dias (2016). It is, therefore, necessary to elicit also the discourses of these subjects that disturb, blur, erase the norms based on heteronormativity. To give voice to those who have for a long time been anonymous or excluded from the school learning process is necessary to put forward a school curriculum lined up to the Queer pedagogy (DIAS; MENEZES, 2017; DIAS, et al., 2017).

In recent years, we have been influenced by the post-structuralist and post-critical readings that have enabled, and are enabling the processes of deconstruction of teachers and researchers. This is not an easy task, but it is possible since we always seek for possibilities of deconstruction and unlearning (HURTADO, 2015). These post-critical readings help us to reflect on our vision at the school curriculum, this has been from the perspective of a subject with a "deconstructed" and "influential" vision (GASTALDO, 2012).

We are not interested in thinking about the curriculum from a single place, perspective and/or possible neutrality. But rather, the curriculum that happens in classrooms, in everyday life, as a cultural, and political act (SILVA, 2013; JUNIOR, 2019), where the asymmetries, androcentrism, sexism, racism, and heterosexism become deprived of the perspective of difference. The school, by itself, is already diverse. What interests us is what we do with the difference.

Feminist and queer pedagogy are contributing to reflect on diversity and the difference of the school, as both seek to promote "awareness, empowerment and collective organization for the transformation of the relations of gender domination and the liberation of individuals, and groups of what limits their social, intellectual and political participation" (CARVALHO; ANDRADE; MENEZES, 2009, p. 37, our translation). Its applicability will necessarily express the dialogue and critique of the culture of power, stimulating a look and analysis for the school curriculum, for the classrooms and other socialization spaces of questioning and change (DIAS, 2018; DIAS, AMORIM, 2015; SANTANA; SANTANA, 2014).

One of the main questions is to understand the school as a "place" of socialization, construction and learning of fundamental values for citizenship and social life. Contents such as 
cultural diversity, human rights, gender equity, diversity, and sexual identification, ethnic relations, indigenous peoples, environmental sustainability, class, religious diversity, generation, among others, need to gain visibility and broad debate in basic education (DIAS; CRUZ, 2014; PINTO, CARVALHO; RABAY; 2017, PAULA; EVANGELISTA, 2019). This is what Queer pedagogy proposes. Thinking of learning by differences at school, as well as an "education that did not impose pre-established models of being, of understanding and of classifying one another" (MISKOLCI, 2013, p. 55, our translation).

For Queer Pedagogy, education and the curriculum would need to stop producing "biopolitical normalization for the state and become a social vehicle for the deconstruction of a historical order of inequalities and injustices" (MISKOLCI, 2013, p. 55, our translation), understanding that the learning process goes beyond classrooms and school walls. It contributes to problematizing our daily life and social relations, reflecting on the aspects that make the school a space destined to the reproduction of hegemonic and heterosexist values, according to the argument presented by Bento (2011). Bento's "normal-body production engineering" can be used as a priority argument for the deconstruction of the "possible" neutrality of the school curriculum, as well as assumptions anchored in androcentric, racist, and heterosexist ideas. This confirms the role of education and the school curriculum as regards the production of broader learning, which impacts on the exercise of citizenship, questioning the technologies of production of normal, adherent or "normal" bodies that need to be questioned.

The approach of queer pedagogy is influenced by the emergence and dissemination of queer studies. Queer studies allow us and help us reflect on the "ambiguity, multiplicity and fluidity of sexual and gender identities, but also suggests new ways of thinking about culture, knowledge, power, and education" (LOURO, 2015, p. 48-49). But how can this perspective be articulated to education? What space will it have in the school curriculum for the transgression of normalizing, disciplinary and binary practices? What changes do pedagogical practice and school experience propose?

According to Silva (2013, p. 107), the queer approach becomes an "epistemological attitude that does not confine itself to sexual identity and knowledge but is meant for knowledge and identity in general. "An action that "means questioning, problematizing, challenging all wellbehaved forms of knowledge and identity." Being Queer is a "criticism of the practices of normalization that occur in the study of sexuality. [...] It refers to a set of knowledge (rather than a systematized and finished theoretical corpus) and to a political disposition "(TRUJILLO, 2015, p.1536, our translation). In this sense, we consider that queer pedagogy proposes a new political 
stance for everyone at school, inserting new strategies, attitudes, pedagogical procedures and subversive positions in the daily school life.

Queer should be understood as an adjective and as a movement, action, as a verb: to turn the school queer, as well as the classrooms, knowledge, methodologies (and social movements, public space, etc.). A queer pedagogy, as stated by Luhman (1998), must go beyond the incorporation of queer content in curricula and concern for the search for teaching strategies that make this content more accessible to students; And I write this as I think that it is often inevitable to move between the urgency of everyday practice (but how do we bring it all into the classroom?), analysis and reflection. (TRUJILLO, 2015, p.1537, our translation).

In identifying itself with queer presuppositions, we have tried our daily actions in schools, in the search to develop a living, fluid, and preoccupied work not only with specific contents to be worked, but with actions that intensify the senses that we attribute to the learning process and relationships, reflecting on the act of learning from the students and with the students.

Proposing unlearning to the curriculum, is closely linked to the process of diverting us from state-normalized pedagogical work, as in Brazil it is put into educational policies, to work on themes considered "eccentric", "deviant" or "intolerable". Perhaps, this is, in fact, the most profitable route for the problematization of several issues pointed out in other researches (DIAS, CARVALHO, OLIVEIRA, 2016, DIAS, CRUZ, 2015, DIAS, AMORIM, 2015). In general, these surveys show that some schools still developing regulatory norms of biopower and governance in the bodies of students and professionals, such as a) prohibiting the use of the toilet by transvestites and transsexual people; b) production of educational practices that educate boys and girls for the annulment of the body; c) investment in the distance between body and mind; d) developing a language that standardizes masculinities and femininities; e) in daily situations it despises the experiences and interrelations of students and teachers.

Although this research and many others point out the fragile or timid work with a difference in the school curriculum, the inclusion of the queer perspective in education and the curriculum proposes unlearning at school, since it is not looking for definitive or absolute certainties. The school experience is much more than knowledge transmission, it is closer to the creation of a new condition of learning knowledge, in which it encompasses a less predictable and more unbalanced process of getting involved in knowledge (TRUJILLO, 2015).

Although the results of our research point to the (re)production of normal bodies at school, this process is not passive. There is resistance and coping, as pointed out by Dias, et al., (2017). The authors point out, from some scenes of the research field, carried out in different times and spaces, that in the educational practices, and in the spaces that they happen, there are several gaps 
of subversion of the norms and control of the bodies, as well as they show that these places are places for disputes, which in our researches we do not generally privilege the discourses that subvert (DIAS et al., 2017). Based on this press, we believe that it is necessary to disseminate these school experiences that play a part in Queer pedagogy and curriculum.

The scenes we present in this text, bring in themselves the purpose of contributing to exemplify the potentialities that queer pedagogy brings to the school curriculum. They are part of the field notes of the second author of this text and are part of the ongoing research titled "Ripping uniforms and turning gender identities in school space" developed in the Postgraduate Program in Education of the Federal University of Sergipe. The ethnographic research aims to assess whether the corporal expression of gay and lesbian students in the school space contributes to the widening of the debate about gender and sexual diversity at school; to reflect the paths and obstacles encountered in the course of the schooling of gay students and their insertion in school curricular practices; verify if there is evidence of destabilization to gender norms from the presence of gay and lesbian students in the institution; to identify whether the existence of gay and lesbian students in basic education has led to curricular changes.

\section{An innovative school? A queer curriculum?}

We took as an area of problematization, the State School Dr. Antônio Garcia Filho , a school in the central-southern territory of the state of Sergipe, where the second author of this text has acted as a teacher for almost two decades and witnessed several educational practices that carried out multicultural scenes that mobilized the entire local population, which always awaited the diverse cultural activities of a school that opened its doors to the community.

Some of these unusual activities in other schools - gay June queen contest, gay country wedding, Candomblé presentations, drag shows, among others - began to promote different feelings in people, from the coexistence with the differences. These records are part of the memorial of the school, the students, the other school agents, and the city. Although some schools still develop regulatory practices, as we have pointed out above, does Garcia Filho produce other knowledge? And what knowledge are these? What pedagogical practices are presented when certain postures were adopted in relation to the insertion of some subversive bodies in their daily activities?

We do not intend to find answers or new truths. Nevertheless, we intend to problematize and to allow reflections about other experiences of pedagogical work with the difference at school. However, it was the opening and/or adoption of school practices that prioritized respect for 
diversity and problematization of difference, within difference. The memories brought by the second author of this text can give us clues about how the school has recognized that diversity and difference have played an important role in education in the multicultural context and in recognizing differences.

In the interviews, and tests carried out at the first moment of the project "Ripping uniforms and turning gender identities at school", the first results showed part of the history of the students. In their speeches, there were continuous references to scenes of homophobia during their school lives, many of them occurring in classrooms and brought about by teachers, who allegedly do not know how to deal with or were not prepared to deal with differences in the school space. For instance, when a student talks about his sexuality in high school but talking about it intersecting with memories of the school life:

[...] Now yes! Now I feel comfortable and reliable. A few years ago no, I did not feel ... comfortable. Because I suffered a lot of bullying because of my hair. I was forced to attack a classmate because of the prejudice that was very present ... I have the case of a Physical Education teacher. One day, on Thursday, and ... the exercise would be soccer, I do not like soccer! I am not obligated to do it so, either! She made me play soccer in her class, and I said I would not play soccer in her class, and she said that while I was in her class I should play soccer, yes, in her class I was a man, I had to be a man in her class ... (STUDENT FROM THE SCHOOL, 2016) ${ }^{1}$.

In the mentioned section, it is clear the signs of disrespect and normalization, which is common within a heteronormative culture, and this kind of conflict and abuse appear in the most common situations. Since in the mentioned event we can observe how certain events could open spaces of low-self-esteem and or school dropout, and even personal traumas. The student interviewed shows discomfort while he is revisiting his memories. Although he says that nowadays he is more confident and more comfortable, there is a part of his subjectivity that is and can be marked negatively and uncomfortably, his hands were restless all the time and his eyes showed it. When he said that he did not like soccer at the time, there was a moment of full conviction about what he did not identify himself with, and he confirms this by saying "I am not obliged", a speech that expresses empowerment, that could be translated into this: I do not force myself to what others force me to! And if we could verify the whole interview, we would verify other talks about their tastes, their preferences regarding the sports, as well as their permanency strategies at school and

\footnotetext{
${ }^{1}$ This testimony was extracted from the ongoing research " Ripping Uniforms and Torning Gender Identities in School Space" from PPGED/UFS. Informing that the second author has permission to use the statements and images used in this text, respecting the ethical agreement between researcher and participants.
} 
during the classes of physical education, speeches that will be analyzed and will point out more results later in the conclusion of the research.

Many of the interviews indicated a certain comfort in relation to the school in which the students interviewed are currently studying. The eight interviewees interviewed said that they liked Garcia because they could be themselves there. In their daily life, they can wear make-up, high heels and have colorful nails. In many of the activities, the school includes them in a very natural way.

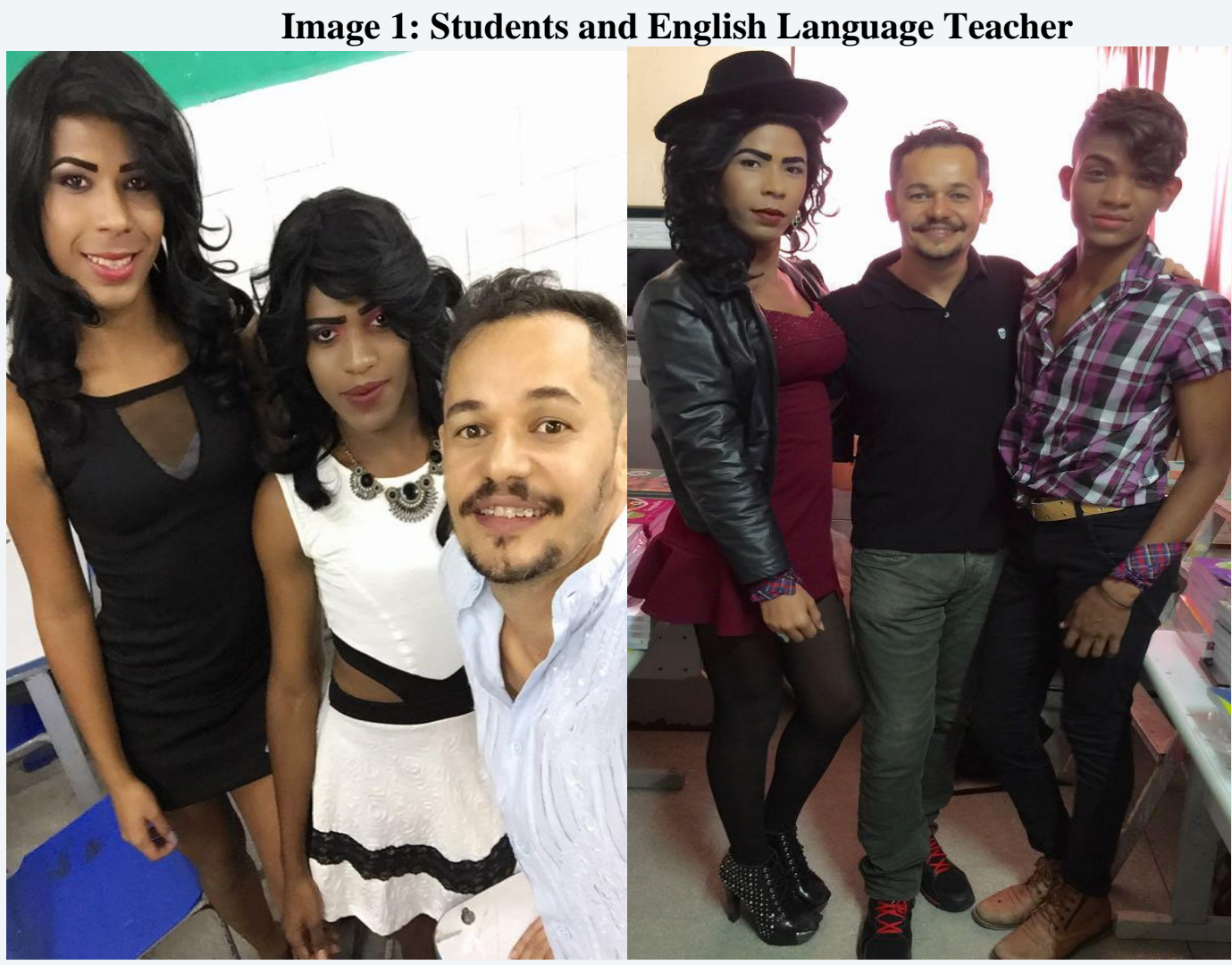

Source: Own Collection, 2017.

Despite references to moments of homophobia, what prevails is the idea of a school where these bodies can be featured, can gain greater visibility, and where the school scenes/events that were chosen from the mentioned text at different times and differences school subjects are an attempt to give an overview of some pedagogical actions of the school, and how the differences are negotiated in the daily routine.

\section{Working with religious diversity}

In 2015, a project for the production of films, in fact, short films, on the theme of Diversity and other school contents, such as grammar and other more formal subjects of the traditional school curriculum, had been devised. The project had been baptized GarFi Club, alluding to the 
name of the school itself. One of the most watched and commented films of this project was The Religious intolerance in the school environment, according to the description of the project, the main purpose was to communicate and involve the school community - a description posted along with the video itself on the YouTube channel. It should be noted that the text, direction, and production of the film was a responsibility of the students involved, however other school agents participated in the film: teachers and school board, which also marks the protagonism given by the school to the students.

The film is all narrated from the idea of respecting religious differences, and although the central theme is religious intolerance in the school environment, its ideas and values represent much of the beliefs of the pedagogical model adopted by the school, considering a pedagogy of valorization of the subject, her/his trajectory, and personal beliefs, elements common to the queer pedagogy.

Making a film about religiosity and religious experiences prejudice within the school in relation to its manifestations, serves to illustrate how the school handles and educates students from the conception of the "curriculum as an ethnic-racial narrative"(SILVA, 2013). Let us consider that most of the scenes of the short film are carried out by a Candomblé believer student, this serves to approximate and demystify prejudices regarding African matrices religions, as well as to mark the pedagogical positions that share the intentions of the school. The marks of a curriculum as an ethnic-racial narrative, support other issues such as feminism, gender equality, bullying in the school environment, among other things.

\section{Video production "The woman who sold her husband for R\$1.99"}

Here it follows the description and analysis of another example of how the school practices give voice to silenced subjects. The central issue of the video described concerns gender equality and the core issues of feminism, such as female empowerment. The video was published on the social network YouTube and viewed so far by 1,438 people, it serves as an example of how the school can put its thinking and its pedagogical innovations beyond school.

The text addresses the life of a woman who is exploited by an alcoholic husband, characters common in the families and lives of many of the students of this school. One day, this woman decides to sell her husband for a small amount of money - in the process of selling and developing the narrative-story it is possible to realize how other social issues are problematized, such as alcoholism, hunger and extreme poverty, social brands present in much of the community where the school is located - what this shows us is the intention and the commitment of this school with 
issues that the school embraces in its transformative curriculum that does not leave out scenes and experiences of its own students.

\section{We love dancing Project}

Between 2008 and 2010, three versions of the We love dancing! The project was carried out, which aimed to promote presentations of street dance groups, with its first version counting with 14 groups and its last with more than 40 groups composed of students from all years of elementary and high school education of the institution.

We love dancing! began to be thought of at the beginning of the 2008 school year, when all the content was chosen to be worked during the year, from the concern of the teaching staff of the High School on how to work the official content of the entrance exam and at the same time to associate with other practices. To do so, a selection of texts was made that together formed the thematic axis "Art and quality of life": Live a healthier life; live longer; The Beatles; The Peacock and The Crow; The Sicmillion megawatt smile2.

After the textual choice, grammatical content and textual inferences were given in each of the two months preceding the last one. The texts were worked in several ways: lectures, film games, English writing of healthy recipes, songs, and fable rewriting, among others.

The students watched the movie Aeon Flux and produced reports about the movie Honey. Then chat wheels were held so that the students could expose their views on the story of the character Honey Daniels, taking this work as an example for altruistic attitudes towards life. In addition to the two films, two other titles were suggested for the students to attend at home: Take the lead and Step up, all titles suggested have thematic similarities.

Subsequently, the students were divided into groups so that they could create choreographies over American pop songs, being discouraged by the teacher, texts that stimulated unsafe sex, violence, drugs and especially vulgarization of women, common in videos passed by the media. The conclusion about the appropriateness of the text was after translation work and observation of words; from there the groups transposed their readings for the body language required in the dance.

The groups presented themselves to the school community and others interested in appreciating the work of the school. In addition to the school groups, other groups were present in some of these presentations, composed by students from a municipal school that attended socially vulnerable adults, a group of elderly people, and a group of students from another municipality.

\footnotetext{
${ }^{2}$ Description performed by the foreign language teacher.
} 
The diversity of dance types and the need for teamwork during the months prior to the culmination of the project allowed the students to interact and get closer to each other, since they spent a lot of time together, including weekends rehearsing their choreography, it was noticed that there was a great mobilization of gay and lesbian students to lead the coordination of the work.

\section{Image 1: Student Dance Presentations}
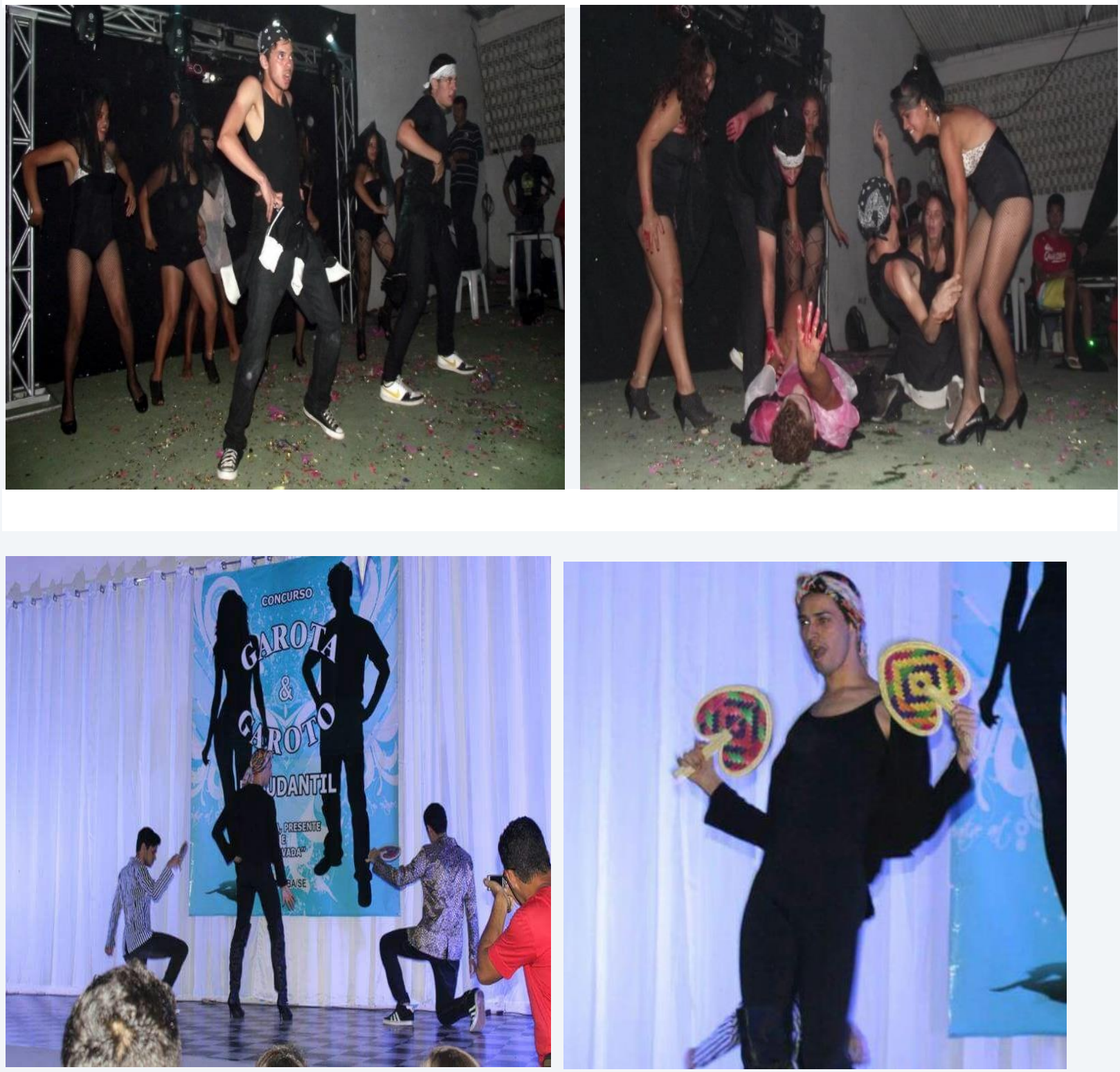

Source: Own Collection, 2017.

In addition to gender issues, the respect for bodies is also evident, in some replica presentations by media artists, the beauty standard imposed by the media was broken, it was possible to see Beyoncé well overweight, scenes of transvestites - even authorized by their parents - and the presentation of groups of marginalized dances such as hip hop, rhythms historically 
linked to black culture, but which on the stage of the school acquired different colors and pedagogical possibilities.

It is necessary to develop a careful analysis of the cultural artifacts we chose to analyze only the testimonies and memories of one of the authors and the images of some of the presentations of the students, searching for "visible" statements (FOUCAULT, 2016). Thus, we consider important the use of images, since they are a "discursive and enunciative, visible text that also tells our contemporary history" (SCHWENGBER, 2014, p. 265, our translation). Thus, the images contribute to our analysis of the didactic strategies of diversity and difference themes, as well as a queer posture in the curriculum.

According to Schwengber (2014: p. 264-265) the images "produce and convey, in their plastic forms, aesthetic, political and social conceptions." We take the images as a discursive statement that deconstructs norms in the contemporaneous, from the meanings of the attempt to read through the fluency of language, as well as through the establishment of meanings and rationalization (SILVA, 2013). Thus, the institution, using visible statements linked to the deconstruction of a language, linked to a discursive network that tries to determine over the years, culture, behavior models, profiles, aesthetic practices and stimuli to heteronormative desire, propose unlearning and the construction of a re-signified knowledge.

The pictures highlighted here produce knowledge and learning that stimulate confrontation with heteronormativity discourse, especially when we deal with gender and sexuality in school.

So can we consider these practices as innovative in what refers to pedagogical work with a difference? Are there any signs of a queer curriculum? Although the scenes do not allow us to analyze this curriculum in depth, they allow us to reflect on innovative pedagogical practices that stimulate the reflection of the limits and challenges that the discussions of gender, sexual diversity, ethnic relations, class, education, and society.

By disrupting gender and sexuality, combating racism and religious intolerance, school is alienating the curriculum as it stands and demarcating possibilities of negotiation in the school space, as far as the performativity of the body can be negotiated in the interaction. In the words of Louro (2015, p. 49-50, our translation), pedagogy and a queer curriculum:

They would be focused on the process of producing differences and would work, centrally, on the immediacy and precariousness of all identities. By putting into question the ways in which the "other" is constructed, they would lead to questioning the narrow relations of the self with the other. The difference would cease to be outside, on the other side, alien to the subject, and would be understood as indispensable to the existence of the subject himself: it would be inside, interacting and constituting the self. 
We believe that a queer pedagogy would work with all bodies, identities, and subjectivities. It would have the power to disturb, destabilize, to propose deconstructions and unlearning. Teaching can transform, and didactic experiences like these propose deconstructions in our conceptions of why, how and for what to teach. From queer experience, we affirm the importance of dialogical pedagogical practice, to bring to the classroom and to produce knowledge for all the voices, without overshadowing and/or not recognizing them in this field.

As Pinar (1998) argues, a queer pedagogy "displaces" and "decentralizes". We do not have to recognize it, but rather let it escape, move, decentralize. We do not need new frames, but new positions. We believe that a good start would be to become suspicious of the school curriculum. This may be one of the innovations queer pedagogy proposes to the school curriculum today.

\section{REFERENCES}

ALMEIDA, Wilson Ricardo Antoniassi. Uniforme escolar e uniformização dos corpos. Revista Tempos e Espaços em Educação, v. 10, n. 22, p. 09-22, maio 2017. doi: https://doi.org/10.20952/revtee.v10i22.6134

ALCÂNTARA, Juliana Nascimento de; DIAS, Alfrancio Ferreira; GIVIGI, Rosana Carla do Nascimento. Play at child education: problematizing gender relations in school. Educação (UFSM), Santa Maria, p. e20/ 1-21, 2019.

BENTO, B. Na escola se aprende que a diferença faz diferença. Estudos Feministas, v.19, n.2, pp. 549-559, mai-ago, 2011.

BRITO, R. S.; PRADO, J. R.; NUNES, C. P. As condições de trabalho docente e o pós-estado de bem-estar social. Revista Tempos e Espaços em Educação, v. 10, n. 23, p. 165-174, 2017. DOI: https://doi.org/10.20952/revtee.v10i23.6676

CADILHE, Alexandre José; DE CASTRO, Roney Polato. “Os comentários é que valeram a pena": práticas de letramento e heteronormatividade em rede social. Revista Práxis Educacional, Vitória da Conquista, v. 15, n. 35, p. 470-489, out. 2019. Disponível em: http://periodicos2.uesb.br/index.php/praxis/article/view/5693. Acesso em: 20 dez. 2019. doi: https://doi.org/10.22481/praxisedu.v15i35.5693.

CARVALHO, M.E.P.; ANDRADE, F. C. B.; MENEZES, C. S. Equidade de gênero e diversidade sexual na escola: por uma prática pedagógica inclusiva. João Pessoa: EDUFPB, 2009.

CARVALHO, M.E.P, et al. Direitos humanos das mulheres e das pessoas LGBTQI: inclusão da perspectiva da diversidade sexual e de gênero na educação e na formação docente. João Pessoa: EDUFPB, 2016.

CARDOSO, Helma de Melo; DIAS, Alfrancio Ferreira. Representações sobre corpo, gênero e sexualidades de estudantes das licenciaturas do Instituto Federal de Sergipe, campus Aracaju. Revista Práxis Educacional, Vitória da Conquista, v. 13, n. 24, p. 76-94, out. 2016. 
Disponível em: http://periodicos2.uesb.br/index.php/praxis/article/view/930. Acesso em: 20 dez. 2019. doi: https://doi.org/10.22481/praxis.v13i24.930.

CRUZ, Maria Helena Santana. A Crítica Feminista à Ciência e Contribuição à Pesquisa nas Ciências Humanas. Revista Tempos e Espaços em Educação, p. 15-28, out. 2014. Doi: https://doi.org/10.20952/revtee.v0i0.2949

DIAS, Alfrancio Ferreira; MENEZES, Carlos André Araújo. Que inovação pedagógica a pedagogia queer propõe ao currículo escolar?. Revista Tempos e Espaços em Educação, v. 10, n. 23, p. 37-48, out. 2017. Doi: https://doi.org/10.20952/revtee.v10i23.7443

DIAS, A. F. et al. Schooling and subversions of gender. Revista Tempos e Espaços em Educação, v. 10, n. 22, p. 83-92, maio 2017. Doi: https://doi.org/10.20952/revtee.v10i22.6433

DIAS, Alfrancio Ferreira. Como as escolas educam corpos nas práticas pedagógicas?. Revista Tempos e Espaços em Educação, p. 103-112, abr. 2014. Doi:

https://doi.org/10.20952/revtee.v0i0.2958

DIAS, Alfrancio Ferreira; AMORIM, Simone. Body, gender and sexuality in teacher training: a meta-analysis. Educar em Revista, Curitiba , n. 56, p. 193-206, June 2015. Doi: http://dx.doi.org/10.1590/0104-4060.40998.

DIAS, A. F.; MENEZES, C. A. A. Que inovação pedagógica a pedagogia queer propõe ao currículo escolar?. Revista Tempos e Espaços em Educação, São Cristóvão, v. 10, n. 23, p. 3748, 2017. DOI: https://doi.org/10.20952/revtee.v10i23.7443.

DIAS, Alfrancio Ferreira. Formative and professional narratives of a transsexual teacher. Educar em Revista, Curitiba, v. 34, n. 70, p. 255-271, Aug. 2018. Doi: http://dx.doi.org/10.1590/0104-4060.57415

DIAS, A. F. et al. Representações sobre corpo, gênero e sexualidades ao longo da vida: discursos de estudantes de Pós-graduação em Educação. Revista Cocar, v. 9, n. 17, p. 135-145, jan./jul. 2015.

DIAS, A. F.; CARDOSO, H. M. . Subversões de Gênero nas Instituições Formativas. Cadernos de Educação, Tecnologia e Sociedade, v. 9, p. 351-358, 2016.

DIAS, Alfrancio Ferreira; OLIVEIRA, Danilo Araujo de. As abordagens de corpo, gênero e sexualidades no Projeto Político Pedagógico em um Colégio Estadual de Aracaju, SE. HOLOS, [S.1.], v. 3, p. 259-271, jul. 2015. Doi: https://doi.org/10.15628/holos.2015.3084

EUGÊNIO, Benedito Gonçalves. O currículo na educação de jovens e adultos: entre o formal e o cotidiano numa escola municipal em belo horizonte. Revista Práxis Educacional, Vitória da Conquista, v. 4, n. 4, jan./jun. 2008. Disponível em:

https://periodicos2.uesb.br/index.php/praxis/article/view/570. Acesso em: 18 dez. 2019.

FERREIRA, Maria Mary. Relações de Classe e Gênero na Escola: revisitando conceitos de igualdade, desigualdade, diferença, classe e gênero. Revista Tempos e Espaços em Educação, p. 57-68, out. 2014. Doi: https://doi.org/10.20952/revtee.v0i0.2952 
ANJOS, Juliana Prochnow; CARDOSO, Lívia de Rezende. Hanami ou corpos fogem, vazam, escapam.... Revista Tempos e Espaços em Educação, p. 69-78, out. 2014. Doi: https://doi.org/10.20952/revtee.v0i0.2953

FOUCAULT, M. Microfísica do poder. Rio de Janeiro: Graal, 2015.

FOUCAULT, M. Arqueologia do Saber. $8^{\text {a }}$ ed. Rio de Janeiro: Forense Universitária, 2016.

FULLAGAR, S. A physical cultural studies perspective on physical (in)activity and health inequalities: the biopolitics of body practices and embodied movement. Revista Tempos e Espaços em Educação, v. 12, n. 28, p. 63-76, 1 jan. 2019. DOI: https://doi.org/10.20952/revtee.v12i28.10161

GASTALDO, D. Pesquisador/a descontruído/a e influente? Desafios da articulação teoriametodoligia nos estudos pós-críticos. In: MEYER, D.E.; PARAÍSO, M.A. (orgs.). Metodologias de Pesquisas Pós-críticas em Educação. Belo Horizonte: Mazza Edições, 2012.

GOMES-DA-SILVA, P. N. Pedagogia da corporeidade: o decifrar e o subjetivar na educação. Revista Tempos e Espaços em Educação, v. 7, n. 13, p. 15-30, 2014. Doi: https://doi.org/10.20952/revtee.v0i0.3255

HURTADO, Inmaculada Gómez. Estrategias organizativas y didácticas para atender a la diversidad: una mirada desde el dirección escolar. Revista Práxis Educacional, Vitória da Conquista, v. 12, n. 22, p. 97- 131, out. 2015. Disponível em:

http://periodicos2.uesb.br/index.php/praxis/article/view/885. Acesso em: 20 dez. 2019.

KOVACS, H.; TINOCA, L. Unfreeze the pedagogies: introduction of a new innovative measure in Portugal. Revista Tempos e Espaços em Educação, v. 10, n. 23, p. 73-86, 2017. DOI: https://doi.org/10.20952/revtee.v10i23.7446

LARROSA, J. J. Notas sobre a experiência e o saber de experiência. Revista Brasileira de Educação, n. 19, p. 20-28, jan./abr. 2002.

LOURO, G. L. Um corpo estranho: ensaios sobre sexualidade e teoria queer. $2^{\mathrm{a}} \mathrm{ed}$. Belo Horizonte: Autêntica, 2015.

KOVACS, H.; TINOCA, L. Unfreeze the pedagogies: introduction of a new innovative measure in Portugal. Revista Tempos e Espaços em Educação, São Cristóvão, v. 10, n. 23, p. 73-86, 2017. Disponível em: https://seer.ufs.br/index.php/revtee/article/view/7446. Acesso em: 3 jan. 2020.

MARÍN, Jorge Garcia. Educación y reproducción cultural: el legado de Bourdieu. Revista Práxis Educacional, Vitória da Conquista, v. 2, n. 2, jan./dez. 2006. Disponível em: https://periodicos2.uesb.br/index.php/praxis/article/view/513. Acesso em: 02 jan. 2020.

MISKOLCI, R. Teoria Queer: um aprendizado pelas diferenças. $2^{\mathrm{a}}$ ed. Belo Horizonte: Autêntica; EDUFOP, 2013.

MOREIRA, A. F.; SILVA JÚNIOR, P. M. DA. Currículo, Transgressão e Diálogo: quando Outras Possibilidades se Tornam Necessárias. Revista Tempos e Espaços em Educação, São 
Cristóvão, v. 9, n. 18, p. 45-54, 11. Disponível em:

https://seer.ufs.br/index.php/revtee/article/view/4962.

MORGADO, J. C. O professor como decisor curricular: de ortodoxo a cosmopolita. Revista Tempos e Espaços em Educação, São Cristóvão, v. 9, n. 18, p. 55-64, 2016. Disponível em: https://seer.ufs.br/index.php/revtee/article/view/4964.

NASCIMENTO, L. F.; CAVALCANTE, M. M. D. Abordagem quantitativa na pesquisa em educação: investigações no cotidiano escolar. Revista Tempos e Espaços em Educação, v. 11, n. 25, p. 249-260, 2018. DOI: https://doi.org/10.20952/revtee.v11i25.7075

OLIVEIRA, Amurabi Pereira de. Gênero, sexualidade e diversidade no currículo escolar: a experiência do papo sério em Santa Catarina. Revista Práxis Educacional, Vitória da Conquista, v. 11, n. 18, p. 131-151, dez. 2014. Disponível em:

http://periodicos2.uesb.br/index.php/praxis/article/view/804. Acesso em: 20 dez. 2019.

OLIVEIRA, A. M.; GEREVINI, A. M.; STROHSCHOEN, A. A. G. Diário de bordo: uma ferramenta metodológica para o desenvolvimento da alfabetização científica. Revista Tempos e Espaços em Educação, v. 10, n. 22, p. 119-132, 2017. Doi:

https://doi.org/10.20952/revtee.v10i22.6429

PAULA, Maria de Fátima Costa de; EVANGELISTA, Marcia Nico. Currículo e produção de subjetividades. Revista Práxis Educacional, Vitória da Conquista, v. 15, n. 33, p. 186-207, jul. 2019. doi: https://doi.org/10.22481/praxisedu.v15i33.5282.

PARASKEVA, J. M. "Brutti, Sporchi \& Cattivi”: Towards a Non-Abyssal Curriculum. Revista Tempos e Espaços em Educação, v. 9, n. 18, p. 75-90, 2016.

DOI: https://doi.org/10.20952/revtee.v9i18.4966

PACHECO, J. A.; SOUSA, J. O (pós) crítico na Desconstrução Curricular. Revista Tempos e Espaços em Educação, São Cristóvão, v. 9, n. 18, p. 65-74, 2016. Disponível em: https://seer.ufs.br/index.php/revtee/article/view/4971.

PEDRO, N. Ambientes educativos inovadores: o estudo do fator espaço nas 'salas de aula do futuro’ portuguesas. Revista Tempos e Espaços em Educação, São Cristóvão, v. 10, n. 23, p. 99-108, 2017. DOI: https://doi.org/10.20952/revtee.v10i23.7448.

PEREIRA, A. A educação de jovens e adultos no sistema prisional brasileiro: o que dizem os planos estaduais de educação em prisões?. Revista Tempos e Espaços em Educação, v. 11, n. 24, p. 245-252, 2018. Disponível em: https://doi.org/10.20952/revtee.v11i24.6657.

PINAR, W. Introduction. In: PINAR, W. (org.). Queer Theory in Education. New Jersey e Londres: Lawrence Erlabaum Associates Publishers, 1998.

PINTO, Érica Jaqueline Soares; CARVALHO, Maria Eulina Pessoa de; RABAY, Glória. As relações de gênero nas escolhas de cursos superiores. Revista Tempos e Espaços em Educação, v. 10, n. 22, p. 47-58, maio 2017. Doi: https://doi.org/10.20952/revtee.v10i22.6173

RAMOS, M. da C. P. Ambiente, Educação e Interculturalidade. Revista Tempos e Espaços em Educação, v. 5, n. 8, 2012. Doi: https://doi.org/10.20952/revtee.v0i0.2284 
RIOS, P. P.; CARDOSO, H.; DIAS, A. F. Concepções de gênero e sexualidade d@ s docentes do curso de licenciatura em pedagogia: por um currículo Queer. Educação \& Formação, v. 3, n. 8 mai/ago, p. 98-117, 2, maio 2018.

ROSENO, Camila dos Passos; AUAD, Daniela. Formação docente em universidades públicas do Nordeste: gênero como resistência democrática nos currículos. Revista Práxis Educacional, Vitória da Conquista, v. 15, n. 35, p. 273-292, out. 2019.

Doi: https://doi.org/10.22481/praxisedu.v15i35.5682.

RUDD, T.; GOODSON, I. F. Refraction as a tool for understanding action and educational orthodoxy and transgression. Revista Tempos e Espaços em Educação, São Cristóvão, v. 9, n. 18, p. 99-110, 2016. DOI: https://doi.org/10.20952/revtee.v9i18.4968.

SANTOS, Émerson Silva; LAGE, Allene Carvalho. Gênero e Diversidade Sexual na Educação Básica: Um olhar sobre o componente curricular Direitos Humanos e Cidadania da rede de ensino de Pernambuco. Revista Tempos e Espaços em Educação, v. 10, n. 22, p. 69-82, maio 2017. Doi: https://doi.org/10.20952/revtee.v10i22.6042

SANTANA, Anabela Maurício de. Gênero, sexualidade e educação: perspectivas em debate. Revista Tempos e Espaços em Educação, p. 151-168, out. 2014. Doi: https://doi.org/10.20952/revtee.v0i0.2962

SANTANA, José Valdir Jesus de; SANTANA, Marise de; MOREIRA, Marcos Alves. Cultura, currículo e diversidade étnicorracial: algumas proposições. Revista Práxis Educacional, Vitória da Conquista, v. 9, n. 15, p. 103-125, jun. 2013. Disponível em:

https://periodicos2.uesb.br/index.php/praxis/article/view/748. Acesso em: 20 dez. 2019.

SANTOS, José Jackson Reis dos. Especificidades dos saberes para a docência na educação de pessoas jovens e adultas. Revista Práxis Educacional, Vitória da Conquista, v. 6, n. 8, jan./jun. 2010. Disponível em: https://periodicos2.uesb.br/index.php/praxis/article/view/623. Acesso em: 20 out.2015.

SARAT, Magda; CAMPOS, Míria Izabel. Gênero, sexualidade e infância: (Con)formando meninas. Revista Tempos e Espaços em Educação, p. 45-56, out. 2014. Doi:

https://doi.org/10.20952/revtee.v0i0.2951

SCHWENGBER, M. S. V. O uso das imagens como recurso metodológico. In: MEYER, D. E.; PARAISO, M. A. Metodologias de pesquisas pós-críticas em educação. Belo Horizonte: Mazza Edições, 2012.

SILVA JUNIOR, Paulo Melgaço da; AGUIAR, Jonathan Fernandes; MAIA, Maria Vitoria Campos Mamede. Por um cotidiano escolar transgressivo: quando corpos trans interrogam as práticas curriculares. Revista Práxis Educacional, Vitória da Conquista, v. 15, n. 33, p. 472497, jul. 2019. Doi: https://doi.org/10.22481/praxisedu.v15i33.5300.

SILVA, T. D. Documentos de Identidade: uma introdução às teorias do currículo. Belo Horizonte: Autêntica, 2013.

SOUSA, J. M. Currículo-como-vida. In PARAÍSO, M. A.; VILELA, R. A.; SALES, S. R. (Orgs.). Desafios contemporâneos sobre currículo e escola básica. Curitiba: CRV, 2012. 
SOUSA, J. M. Repensar o currículo como emancipador. Revista Tempos e Espaços em Educação, São Cristóvão, v. 9, n. 18, p. 111-120, 2016. DOI:

https://doi.org/10.20952/revtee.v9i18.4969.

SOUSA, J. M. Discutindo conceitos em torno do Currículo. Revista Tempos e Espaços em

Educação, v. 10, n. 23, p. 15-26, 2017. DOI: https://doi.org/10.20952/revtee.v10i23.7441

SOUSA, Jesus Maria. Um olhar etnográfico sobre o currículo. Revista Práxis Educacional, Vitória da Conquista, v. 13, n. 25, p. 18-35, abr. 2017.

Doi: https://doi.org/10.22481/praxis.v13i25.952.

SOUZA, Liliane Pereira de. Educação, gênero e raça: Mapeando algumas desigualdades. Revista Tempos e Espaços em Educação, p. 113-124, out. 2014. Doi: https://doi.org/10.20952/revtee.v0i0.2959

TRUJILLO, G. Pensar desde otro lugar, pensar lo impensable: hacia una pedagogía queer. Educ. Pesqui., São Paulo, v. 41, n. especial, p. 1527-1540, dez., 2015.

THÜRLER, Djalma; DOS SANTOS, Josué Leite. Um debate sobre a escola como tecnologia político-cultural. Revista Tempos e Espaços em Educação, p. 29-44, out. 2014. Doi: https://doi.org/10.20952/revtee.v0i0.2950

ULJENS, M. Non-Affirmative curriculum theory in a cosmopolitan era? Revista Tempos e Espaços em Educação, São Cristóvão, v. 9, n. 18, p. 121-132, 2016. DOI:

https://doi.org/10.20952/revtee.v9i18.4970.

\section{SOBRE OS AUTORES:}

\section{Carlos André Araújo Menezes}

Master's Degree in Education by the Post Graduate Program in Education of the Federal University of Sergipe - Brazil. Teacher of Portuguese and Foreign Language in Basic Education SEED/SE. E-mail: aramen2005@ hotmail.com

(iD http://orcid.org/0000-0002-0415-394X

\section{Alfrancio Ferreira Dias}

Sociology PhD (UFS). Professor of the Department of Education and the Post-Graduate Program in Education of the Federal University of Sergipe - Brazil. E-mail: diasalfrancio@gmail.com

(iD) http://orcid.org/0000-0002-5562-0085

\section{Madson de Santana Santos}

Graduating in Languages (Portuguese and English), Scholarship holder (CNPq) and Junior Reseacher in Federal University of Sergipe - Brazil. E-mail: madson341@ @mail.com

(iD) http://orcid.org/0000-0003-4558-8218 